\title{
Hemafereza lecznicza w świetle danych przedstawionych w czasie 36. Międzynarodowego Kongresu ISBT (kongres wirtualny, 12-16 grudnia 2020 r.). Cześć I - plazmafereza lecznicza
}

\author{
Therapeutic hemapheresis in light of the presentations at the 36th \\ International ISBT Congress Virtual meeting, 12-16 December 2020. \\ Part I - therapeutic plasmapheresis
}

\author{
Aleksandra Rosiek (i) \\ Zakład Transfuzjologii Instytutu Hematologii i Transfuzjologii w Warszawie
}

\begin{abstract}
Streszczenie
Wramach 36. Międzynarodowego Kongresu ISBT (kongres wirtualny, 12-16 grudnia 2020 r.) hemaferezie leczniczej poświęcono tacznie 22 doniesienia omawiajace różne aspekty stosowania tej metody leczniczej. Przedstawiono dane dotyczqce wykorzystania wybranych technik hemaferezy (plazmafereza, cytafereza, fotofereza) w niektórych chorobach $i$ stanach klinicznych. Najwięcej doniesień (8) pochodzito z Hiszpanii (w tym jedno we wspótpracy ze Stanami Zjednoczonymi), po 2 z Korei $i$ ze Sri Lanki. Przedstawiono również pojedyncze doniesienia z Polski, Wielkiej Brytanii, Indii, Meksyku, Omanu, Bangladeszu, Argentyny i Izraela.

Większość doniesień (14) poświęcono zagadnieniom zwiazanym ze stosowaniem plazmaferezy leczniczej - między innymi w neurologii i w przypadkach zakrzepowej plamicy matoptytkowej. Niniejsza, pierwsza czesść sprawozdania jest poświęcona prezentacjom dotyczqcym w całości lub czéściowo zastosowań plazmaferezy leczniczej, natomiast doniesienia poświęcone cytaferezie leczniczej i fotoferezie zostana przedstawione w cześci drugiej.
\end{abstract}

Słowa kluczowe: hemafereza lecznicza, plazmafereza

J. Transf. Med. 2021; 14: 32-40

\section{Wstęp}

W ramach 36. Międzynarodowego Kongresu ISBT (kongres wirtualny, 12-16 grudnia 2020 r.), hemaferezie leczniczej poświęcono część sesji plakatowej obejmującej zagadnienia z zakresu transfuzjologii klinicznej. Prezentacje poszczególnych prac zostały umieszczone na stronie internetowej kongresu w postaci filmów zawierających slajdy $z$ nagranym komentarzem autorskim. Ponadto jedna $z$ prac dotyczących plazmaferezy leczniczej została przedstawiona w ramach sesji poświęconej prezentacji wyników badań klinicznych. 
Przedstawiono łącznie 22 doniesienia omawiające różne aspekty stosowania hemaferezy leczniczej w niektórych chorobach i stanach klinicznych, przy czym:

- w 14 doniesieniach omawiano zagadnienia związane ze stosowaniem plazmaferezy leczniczej;

- 1 doniesienie dotyczyło erytroaferezy leczniczej;

- 1 doniesienie dotyczyło zastosowania leukaferezy;

- 1 doniesienie poświęcono wieloletnim doświadczeniom autorów związanym ze stosowaniem różnych technik aferezy leczniczej;

- 5 doniesień poświęcono fotoferezie.

Najwięcej doniesień (8) pochodziło $z$ Hiszpanii (w tym jedno we współpracy ze Stanami Zjednoczonymi), po 2 z Korei i ze Sri Lanki. Przedstawiono również pojedyncze doniesienia $z$ Polski, Wielkiej Brytanii, Indii, Meksyku, Omanu, Bangladeszu, Argentyny i Izraela.

Niniejsza część sprawozdania jest poświęcona zastosowaniom plazmaferezy leczniczej, natomiast doniesienia poświęcone cytaferezie leczniczej (erytroafereza i leukafereza), a także fotoferezie, zostaną przedstawione w części drugiej.

\section{Plazmafereza lecznicza}

Plazmafereza lecznicza jest obecnie najczęściej stosowaną techniką hemaferezy leczniczej. Najprostsza — i najszerzej stosowana - metoda wykonywania zabiegów plazmaferezy polega na pobraniu osocza pacjenta metodą wirowania lub filtracji i przetoczeniu płynu zastępczego, zazwyczaj przy użyciu specjalistycznego zautomatyzowanego urządzenia (separator komórkowy). Często stosowana nazwa tej techniki to „wymiana osocza” (TPE, therapeutic plasma exchange).

Rzadziej są stosowane selektywne metody oczyszczania osocza polegające na jego separacji i eliminacji różnymi metodami niepożądanych składników. Oczyszczone w ten sposób osocze jest przetaczane zwrotnie choremu, co ogranicza konieczność stosowania płynów zastępczych.

We wszystkich prezentowanych w czasie kongresu doniesieniach dotyczących plazmaferezy leczniczej omawiano różne aspekty stosowania TPE.

Doniesienia dotyczące plazmaferezy leczniczej poświęcono jej zastosowaniom w:

- różnych chorobach i stanach klinicznych (3 prace);

- neurologii (5 prac);
— zakrzepowej plamicy małopłytkowej (TTP, thrombotic thrombocytopenic purpura) (4 prace);

- kardiologii (1 praca).

Ponadto zaprezentowano 2 doniesienia dotyczące przede wszystkim niektórych aspektów technicznych zabiegów TPE (wybór płynu zastępczego).

\section{Zastosowania plazmaferezy w różnych chorobach}

W trzech spośród przedstawionych prac omówiono zastosowania plazmaferezy w różnych chorobach i stanach klinicznych.

Pierwsze $z$ tych doniesień (Naznin i wsp.) zawierało wyniki analizy zabiegów TPE wykonanych w 2018 roku (Transfusion Medicine, Asgar Ali Hospital; Transfusion Medicine, Apollo Hospitals, Dhaka, Bangladesz) [1].

Celem tego badania była ocena wyników stosowania TPE u pacjentów $z$ różnymi chorobami na tle immunologicznym i nieimmunologicznym. Analizowano dane dotyczące demografii, stanu klinicznego pacjentów, liczby zabiegów i objętości wymienianego osocza, a także tolerancji TPE przez pacjenta i powikłań występujących w trakcie lub po zabiegu.

$\mathrm{W}$ analizowanym okresie przeprowadzono łącznie 61 zabiegów TPE u 15 pacjentów w wieku 27-67 lat, między innymi w przypadkach zespołu Guillaina-Barrégo (GBS, Guillain-Barré syndrome), TTP, zespołu Goodpasture. U 11 pacjentów (w tym u chorych $z$ GBS i TTP) stwierdzono poprawę. Powikłania dotyczyły 3,2\% zabiegów i miały charakter hipotensji i łagodnych objawów hipokalcemii.

Autorzy stwierdzają, że TPE jest przydatną pomocniczą metodą leczenia wielu chorób, zwłaszcza na tle autoimmunologicznym, a także chorób układu nerwowego. Jakkolwiek jednak zabiegi TPE mogą się przyczyniać do zmniejszenia śmiertelności i poprawy rokowania pacjenta, nadal są $\mathrm{w}$ Bangladeszu wykonywane tylko w nielicznych specjalistycznych szpitalach.

Drugie $z$ doniesień (Wijesiri) przedstawiało wyniki analizy danych dotyczących zabiegów TPE wykonanych w okresie od 01.02.2017 roku do 31.01.2018 roku w National Hospital of Sri Lanka, Colombo, Sri Lanka [2].

Przeanalizowano dane dotyczące łącznie 102 pacjentów i 535 procedur TPE. Wskazania do zabiegów u 67 pacjentów (66\%) zakwalifikowano do kategorii I według wytycznych Amerykańskiego Stowarzyszenia Aferezy (ASFA, American Society for Apheresis), u 27 pacjentów (26\%) — do kategorii II, 
a u 1 pacjenta $(1 \%)$ - do kategorii III $^{1}$ [3]. Natomiast 7 osób (7\%) nie zostało zakwalifikowanych do żadnej z powyższych kategorii. U 69 pacjentów (68\%) po zabiegu stwierdzono poprawę stanu klinicznego. Nie obserwowano poprawy u pacjentów, u których wskazaniem do zabiegu było zależne od przeciwciał odrzucanie przeszczepu nerki, a także w przypadku stosowania TPE w celu odczulenia pacjenta przed przeszczepieniem nerki.

U 34 pacjentów $(33 \%)$ w przebiegu $45(8,4 \%)$ zabiegów wystąpiły powikłania. Najczęściej obserwowano reakcje alergiczne (31 przypadków).

Autorzy stwierdzają, że TPE jest bezpieczną procedurą leczniczą, którą można stosować z różnych wskazań. Podkreślają przy tym, że w omawianym badaniu u $92 \%$ pacjentów stwierdzono wskazania do TPE kategorii I lub II według wytycznych ASFA, co wskazuje na zasadność większości zabiegów wykonywanych w ich szpitalu.

W doniesieniu pochodzącym z Polski (Rosiek i wsp.) przedstawiono dane dotyczące zabiegów hemaferezy leczniczej wykonanych w latach 1997-2017 w Instytucie Hematologii i Transfuzjologii w Warszawie [4]. Analizowano wskazania do hemaferezy, liczbę zabiegów wykonanych w poszczególnych latach, a także kategorię przypisywaną danemu zastosowaniu hemaferezy leczniczej (HL) według zaleceń ASFA [3].

W omawianym okresie wykonano łącznie 3635 zabiegów u 778 pacjentów, z czego większość stanowiły zabiegi plazmaferezy (2742 zabiegi u 446 pacjentów). Liczba zabiegów przeprowadzonych u poszczególnych pacjentów wynosiła od 1 do 234 .

Większość chorych poddano plazmaferezie w celu wyeliminowania nadmiaru białek patogennych w takich chorobach, jak szpiczak mnogi (1246 zabiegów, 241 pacjentów), ale od 2007 roku obserwowano tu tendencję spadkową. Drugim co do częstości wskazaniem do plazmaferezy była zakrzepowa plamica małopłytkowa (872 zabiegi, 40 pacjentów).

U 104 pacjentów wykonano łącznie 488 zabiegów plazmaferezy $z$ powodu zaburzeń neurologicznych, głównie zespołu Guillaina-Barrégo (257 zabiegów), a także polineuropatii i miastenii. Inne wskazania obejmowały pojedyncze przypadki ziarniniakowatości Wegenera, zespołu Goodpasture’a czy

\footnotetext{
${ }^{1}$ Według wskazań ASFA z 2019 r. wyróżniono cztery kategorie zaleceń do zabiegu aferezy leczniczej:

- kategoria I - afereza jako terapia pierwszego rzutu, stosowana samodzielnie lub w połączeniu z innymi metodami leczenia;

- kategoria II - afereza jako terapia drugiego rzutu, stosowana samodzielnie lub w połączeniu z innymi metodami leczenia;

- kategoria III — optymalne zastosowania aferezy nieustalone, decyzje należy podejmować indywidualnie;

- kategoria IV - opublikowano dowody na brak skuteczności lub szkodliwość aferezy.
}

zespołu Stevensa-Johnsona. Większość z tych zabiegów spełniało kryteria wskazań do stosowania hemaferezy według wytycznych ASFA, chociaż nie zawsze były to zalecenia I kategorii.

Zabiegi były na ogól dobrze tolerowane, a obserwowane niepożądane reakcje dotyczyły reakcji wazowagalnych, lagodnych objawów hipokalcemii i problemów $z$ dostępem naczyniowym.

Autorzy stwierdzają, że plazmafereza jest przede wszystkim zabiegiem o działaniu wspomagającym i paliatywnym, służącym do szybkiej eliminacji czynników chorobotwórczych $z$ krążenia. W wielu stanach klinicznych (np. TTP) jest nadal uważana za ważną metodę leczniczą; jednak w innych (np. szpiczaku mnogim) wydaje się tracić na znaczeniu.

\section{Choroby układu nerwowego}

Wieloośrodkowe badanie AMBAR (Alzheimer Management By Albumin Replacement) przeprowadzono przy wspóludziale autorów ze Stanów Zjednoczonych i Hiszpanii (Lozano i wsp.) [5].

Choroba Alzheimera (łac. morbus Alzheimer, ang. Alzheimer's disease, w skrócie AD) jest nieuleczalną i postępująca chorobą neurodegeneracyjną, prowadzącą do otępienia, a następnie śmierci pacjenta. Charakteryzuje się zewnątrzkomórkową akumulacją amyloidu beta $(\mathrm{A} \beta)$ w mózgu chorego. $\mathrm{A} \beta$ pozostaje $\mathrm{w}$ dynamicznej równowadze między płynem mózgowo-rdzeniowym i osoczem. Co ważne, około $90 \%$ krążącego $\mathrm{A} \beta$ jest związane $z$ albuminami. Dlatego wysunięto hipotezę, że eliminacja $\mathrm{A} \beta$ związanego $z$ albuminą $\mathrm{w}$ osoczu mogłaby doprowadzić do ograniczenia jego akumulacji w mózgu.

Badanie AMBAR miało na celu ocenę możliwości stosowania TPE przy wykorzystaniu roztworu albumin jako płynu zastępczego, jako metody eliminacji $z$ osocza $\mathrm{A} \beta$ i innych patologicznych substancji i spowolnienia dzięki temu postępu choroby. $\mathrm{W}$ omawianym doniesieniu omówiono wyniki badań dotyczących charakterystyki, wykonalności i bezpieczeństwa zabiegów TPE wykonywanych w ramach badania AMBAR u pacjentów $z$ AD. W tym celu losowo przydzielono 347 pacjentów $z$ łagodną do umiarkowanej postacią AD do trzech ramion badania, w których wykonywano TPE, oraz do grupy placebo (pozorowana TPE). Pacjenci przydzieleni do „aktywnych” ramion badania przebyli wspólny 6 -tygodniowy okres cotygodniowej konwencjonalnej TPE: 2500 do $3000 \mathrm{ml}$ osocza pacjenta zastępowano 5-procentową albuminą. Następnie przez 12 miesięcy stosowano wymianę małych objętości osocza. W tym celu pobierano od $690 \mathrm{ml}$ do $880 \mathrm{ml}$ 
osocza pacjenta (postępując jak przy donacji osocza przez krwiodawców) i przetaczano albuminę 20\% (w różnych dawkach w poszczególnych grupach badanych). Ponadto w niektórych grupach stosowano immunoglobuliny do podawania dożylnego (IVIG).

Natomiast w przypadku osób przydzielonych do grupy placebo separator wykonujący zabiegi pracował w obwodzie zamkniętym, bez żadnej wymiany płynów $z$ pacjentem, realistycznie pozorując wykonanie TPE. We wszystkich grupach oceniano częstość występowania zdarzeń niepożądanych, zarówno związanych $\mathrm{z}$ techniką przeprowadzanych zabiegów, jak i ze stosowanymi produktami.

Ogółem badanie ukończyło $72 \%$ pacjentów. Wykonano łącznie 4709 zabiegów TPE, w tym 1223 pozorowane i 3486 prawdziwych.

W przebiegu 501 TPE stwierdzono 637 zdarzeń niepożądanych związanymi z zabiegiem $(10,6 \%)$. Natomiast u 26 pacjentów wystąpiło 51 zdarzeń niepożądanych związanych ze stosowanymi produktami $(1,1 \%$ zdarzeń na pacjenta: $0 \%$ w grupie placebo; od $0,5 \%$ do $0,8 \%$ we wszystkich leczonych grupach). Wystąpiło 60 poważnych zdarzeń niepożądanych (odpowiednio $3,8 \% ; 1,8 \%$ do $5,2 \%$ w poszczególnych ramionach badania).

Wskaźnik zdarzeń niepożądanych w całym badaniu w relacji do liczby wykonanych zabiegów był niski. Zdarzenia te występowały przede wszystkim we wstępnej fazie badania (tj. gdy wykonywano TPE), następnie ich częstość stopniowo spadała.

Autorzy wnioskują, że stosowanie TPE przy wykorzystaniu roztworu albumin jako płynu zastępczego u pacjentów $z \mathrm{AD}$ jest wykonalne i bezpieczne.

Duga $z$ prac poświęconych zastosowaniom TPE w chorobach układu nerwowego (Rivas i wsp.) pochodziła z Hiszpanii (Hospital Clinico Lozano Blesa, Saragossa) [6].

Autorzy omówili zastosowanie TPE w leczeniu autoimmunologicznych chorób układu nerwowego, przy uwzględnieniu wytycznych ASFA z 2019 roku [3]. W tym celu przeprowadzono retrospektywne badanie obserwacyjne dotyczące zabiegów TPE wykonywanych w latach 2015-2019. Oceniano skuteczność TPE pod względem klinicznym, przy uwzględnieniu płci, wieku, liczby zabiegów, zastosowanego dostępu żylnego, rodzaju płynu zastępczego, stosowanego jednocześnie leczenia, powikłań związanych $z$ zabiegiem, a także objawów neurologicznych.

W ciągu 5 lat wykonano łącznie 190 zabiegów TPE u 27 pacjentów - 11 kobiet i 16 mężczyzn (średnio 7 zabiegów/pacjenta); mediana wieku pacjentów wynosiła 53 lata. Jako płyn zastępczy stosowano 5-procentowy roztwór albuminy.
Rozpoznania leczonych chorób to:

— zespół Guillaina-Barrégo (33,3\%);

- miastenia (26\%);

- ostre poprzeczne zapalenie rdzenia kręgowego $(14,8 \%)$;

- zapalenie nerwu wzrokowego $(11,1 \%)$;

- zapalenie wielonerwowe nerwów czaszkowych $(3,7 \%)$;

- rozsiane ostre zapalenie mózgu i rdzenia $(3,7 \%)$;

- limbiczne zapalenie mózgu (3,7\%);

- inne polineuropatie $(3,7 \%)$.

U 92,6\% chorych stosowano jednocześnie dodatkowe leczenie, przede wszystkim kortykosteroidy $(33,4 \%)$, immunoglobuliny $(29,6 \%)$ lub jednocześnie kortykosteroidy i immunoglobuliny (29,6\%). Po zakończeniu serii zabiegów u 62,9\% pacjentów stwierdzono poprawę stanu klinicznego. U 18,5\% pacjentów wystąpiły niepożądane reakcje, przede wszystkim hipotensja, reakcje wazowagalne, drgawki, hipokalcemia i problemy związane $z$ dostępem żylnym.

Większość wskazań do TPE była zgodna $z$ wytycznymi ASFA. $Z$ doświadczenia autorów wynika, że w niektórych chorobach neurologicznych TPE stanowi skuteczną i bezpieczną alternatywę leczniczą.

Trzecia praca dotycząca stosowania TPE w chorobach układu nerwowego (Kaur i wsp.) pochodziła $z$ Indii (Government Medical College and Hospital Chandigarh, India) [7]. Autorzy oceniali bezpieczeństwo i efektywność stosowania TPE u pacjentów w różnym wieku, $z$ chorobami układu nerwowego. $\mathrm{W}$ tym celu przeprowadzono retrospektywną analizę wszystkich zabiegów TPE wykonanych w szpitalu w okresie 6 lat (2014-2019). W zależności od stanu klinicznego pacjenta zabiegi były wykonywane codziennie lub co drugi dzień. Analizowano zaobserwowane zdarzenia niepożądane. W celu oceny odpowiedzi na terapię TPE oceniano stan kliniczny pacjentów przed zabiegiem i po jego wykonaniu (badanie neurologiczne).

Przeprowadzono łącznie 135 zabiegów TPE u 29 pacjentów (20 mężczyzn, 9 kobiet, w tym 7 osób poniżej, a 22 powyżej 18 rż.). Liczba wykonanych zabiegów wynosiła od $1-7 /$ pacjenta (średnio 4,5 zabiegu/pacjenta), przy czym:

- u 21 pacjentów stwierdzono zespół Guillaina-Barrégo;

— u 5 pacjentów — poprzeczne zapalenie rdzenia kręgowego;

- u 3 pacjentów - autoimmunologiczne zapalenie mózgu.

Jako płyn zastępczy u 16 pacjentów (55\%) stosowano osocze świeżo mrożone (FFP, fresh frozen 
plasma), podczas gdy u 13 (44\%) - 4-procentowy roztwór albuminy. Zdarzenia niepożądane obserwowano w 36 zabiegach u 17 pacjentów (26,6\%), przy czym większość $z$ nich dotyczyła przypadków, gdy stosowano FFP; pięciu zabiegów nie ukończono.

U sześciu pacjentów stwierdzono znaczącą poprawę, u 16 osób - odpowiedź częściową, a u 7 zabiegi nie dały efektu.

Zdaniem autorów, zabiegi TPE są bezpieczną i opłacalną alternatywą dla IVIG w leczeniu chorób układu nerwowego. Najbardziej przydatne okazały się w leczeniu zespołu Guillaina-Barrégo, jednak dla uzyskania najlepszych rezultatów należy rozpocząc stosowanie TPE najwcześniej, jak jest to możliwe.

Kolejna praca (Ramos-Coronado i wsp.) pochodziła $z$ Meksyku (Patologia Clinica, Universidad Autónoma de Nuevo León, Monterrey) [8]. Jej celem była ocena stanu klinicznego pacjentów z zespołem Guillaina-Barrégo i Millera Fischera, poddawanym w ciągu 7 lat zabiegom TPE $\mathrm{z}$ zastosowaniem roztworu albuminy jako płynu zastępczego. W tym celu przeprowadzono analize retrospektywną danych dotyczących wszystkich pacjentów, u których w okresie od stycznia 2013 roku do grudnia 2019 roku zastosowano plazmaferezę jako terapię pierwszego rzutu zgodnie $z$ wytycznymi ASFA. Przeanalizowano zapisy w dokumentacji medycznej dotyczące między innymi oceny siły kończyn dolnych, nasilenia duszności, a także czasu trwania hospitalizacji i obserwowanych powikłań.

Oceniono łącznie 36 pacjentów (25 mężczyzn $-69,4 \% ; 11$ kobiet $-30,6 \%$ ), przy czym ich średni wiek wynosił $41,92 \pm 17,82$ roku. U 32 pacjentów (88,9\%) rozpoznano zespół Guillaina-Barrégo, tylko u $4(11,1 \%)$ - zespół Millera-Fischera. Mediana czasu trwania hospitalizacji wyniosła $10 \mathrm{dni}$. Łącznie 22 pacjentów $(61,1 \%)$ doznało w czasie trwania hospitalizacji powikłań. Były to najczęściej: zapalenie płuc związane $z$ wentylacją mechaniczną (10 pacjentów, 27,8\%) i zakażenie dróg moczowych (5 pacjentów, 13,9\%); 12 pacjentów (33,3\%) wymagało stosowania wentylacji mechanicznej. Dwóch pacjentów zmarło podczas trwania hospitalizacji. Po zakończeniu hospitalizacji prowadzono dalszą obserwację 28 pacjentów (77,8\%). Mediana czasu, który upływał do dnia pierwszego badania kontrolnego, wynosiła 2 miesiące.

Tylko u 10 pacjentów $(27,8 \%)$ badania kontrolne przeprowadzono po raz drugi. Późne następstwa choroby wystąpiły u 16 pacjentów (hiporefleksja, opadanie powieki, zmniejszona wrażliwość na bodźce, zmniejszenie siły mięśni).
W podsumowaniu doniesienie zawiera opinię, że wprawdzie znaczenie tej analizy jest ograniczone $z$ powodu niewielkich rozmiarów grupy badanej, jednak istotną obserwację stanowi stwierdzana w czasie pierwszego badania kontrolnego poprawa siły mięśni kończyn dolnych u większości pacjentów.

Ostatnie doniesienie w tej grupie (Al Riyami i wsp.) pochodziło z Omanu (Khoula Hospital, Muscat, Oman) [9]. Autorzy przeprowadzili analizę dotyczącą wszystkich zabiegów TPE wykonanych u pacjentów $z$ chorobami układu nerwowego od marca do grudnia 2019 roku. Analizowano w szczególności wskazania do TPE i ich zgodność $z$ wytycznymi ASFA, a także liczbę i częstość zabiegów, przy uwzględnieniu stanu klinicznego pacjentów i wyników badan laboratoryjnych.

Po zakończeniu terapii dokonywano oceny deficytów neurologicznych pacjenta i na tej podstawie klasyfikowano jego odpowiedź na leczenie jako całkowitą, częściową lub brak odpowiedzi.

W omawianym okresie wykonano łącznie 62 zabiegi. Najczęściej występujące wskazania to zespół Gullaina-Barrego, zapalenie nerwu wzrokowego, miastenia i stwardnienie rozsiane.

Jak ustalono, w tym czasie wszystkie zabiegi TPE wykonano ze wskazań uwzględnionych w wytycznych ASFA [3]. Szczególnie korzystne wyniki obserwowano w przypadkach stanów klinicznych, dla których wyżej wymienione wytyczne zalecają stosowanie TPE jako terapii pierwszego rzutu (Kategoria I) przy wysokim lub umiarkowanym poziomie siły zaleceń (Grade 1A, 1B) [10, 11].

$\mathrm{W}$ przypadkach gdy wskazania do zabiegu należały do innych kategorii, pacjenci reagowali na zabiegi TPE rozmaicie, ale ogólnie występowała u nich tendencja do odpowiedzi częściowej; jednak obserwacja ta nie była statystycznie znamienna $(\mathrm{p}=0,082)$.

Prezentowane wyniki pozwoliły ustalić, $\dot{z}$ e wskazania do TPE w omawianym ośrodku są zgodne $z$ wytycznymi ASFA, a przypadków całkowitego wyzdrowienia można się spodziewać przede wszystkim w przypadku wskazań zaliczanych do kategorii I.

\section{Zakrzepowa plamica małopłytkowa (TTP)}

Dwa spośród doniesień dotyczących TTP pochodziły $z$ Hiszpanii, $z$ tego samego ośrodka (Haematology Service, University General Hospital, Alicante), i zawierały opisy przypadków.

Pierwsze doniesienie (Garzò i wsp.) dotyczyło TTP występującego w przebiegu przewle- 
kłego alkoholowego zapalenia trzustki u 67-letniej pacjentki. Chora została przyjęta do szpitala $z$ powodu pogorszenia stanu neurologicznego, silnego bólu brzucha i pogorszenia samopoczucia w ciągu poprzedzających 24 godzin. Stwierdzono małopłytkowość (liczba płytek $26 \times 10^{9} / 1$ ), a także obecność schistocytów. Podejrzewając TTP, wykonano $\mathrm{w}$ trybie pilnym zabieg TPE, podano także metyloprednizolon dożylnie. Następnego dnia, po otrzymaniu wyniku badania aktywności metaloproteinazy ADAMTS 13 (A Disintegrin-like And Metalloprotease with ThromboSpondin type 1 motif, 13), potwierdzono rozpoznanie TTP (poziom aktywności 2,40\%, obecne przeciwciała anty-ADAMTS13). Po 10 dniach leczenia udało się uzyskać poprawę (liczba płytek $>150 \times 10^{9} / 1$, aktywność ADAMTS13 - 13-54\%), jednak po tygodniu nastąpiło ponowne pogorszenie stanu pacjentki (aktywność ADAMTS13 - 3\%, liczba płytek $24 \times 10^{9} / 1$, objawy neurologiczne). Nie stwierdzono jednak obecności przeciwciał anty-ADAMTS13. Jednocześnie nastąpiło zaostrzenie zapalenia trzustki. Wznowiono zabiegi TPE, przy czym poprawę stwierdzono już po 1 zabiegu; dodatkowo podawano kortykosteroidy i Rytuksymab. Tym razem udało się uzyskać długotrwałą poprawę dotyczącą TTP; pacjentka wymaga jednak nadal leczenia zapalenia trzustki.

Biorąc pod uwagę zbieżność czasową między obserwowanymi zaostrzeniami zapalenia trzustki a rozpoznaniem TTP u pacjentki, autorzy przypuszczają, że istnieje między nimi związek przyczynowy. W piśmiennictwie światowym opisywano już przypadki TTP związane $z$ ostrym zapaleniem trzustki, w których nie stwierdzano obecności przeciwciał anty-ADAMTS13. Niedobór ADAMTS13 przypisuje się $\mathrm{w}$ takich przypadkach innym mechanizmom patofizjologicznym, będącym następstwem stanu zapalnego.

Drugie $z$ doniesień (Campos i wsp.) dotyczyło 19-letniej kobiety, przyjętej do szpitala po porodzie $z$ podejrzeniem TTP [12]. Stwierdzono u niej małopłytkowość (liczba płytek $7 \times 10^{9} / 1$ ) i niedokrwistość (stężenie Hb 6,6 g/dl), a także obecność schistocytów. Rozpoczęto serię codziennych zabiegów TPE. Rozpoznanie TTP potwierdzono, wykonując badanie aktywności ADAMTS 13 (wynik - 0\%), przy obecności przeciwciał anty-ADAMTS13. Zastosowano metyloprednizolon, a po 3 dniach - Rytuksymab według standardowego harmonogramu tygodniowego. Liczba płytek nie wzrosła znacząco, rozpoczęto więc stosowanie zabiegów TPE 2 razy dziennie, a także leczenie immunosupresyjne. Nie uzyskano odpowiedzi i w 20. dniu leczenia zasto- sowano kaplacyzumab; po 4 dniach stwierdzono prawidłową liczbę płytek. Aktywność ADAMTS13 utrzymywała się jednak na poziomie $0 \%$, dołączono więc leczenie mykofenolanem mofetylu i bortezomibem (4 cykle). Po 4 miesiącach leczenia liczba płytek krwi była prawidłowa, uzyskano jednak tylko częściową poprawę aktywności ADAMTS13 (ok. 28\%).

Autorzy wnioskują, że u pacjentów $z$ podejrzeniem TTP leczenie należy rozpoczynać jak najwcześniej, stosując między innymi TPE i leki immunosupresyjne. Istnieją różne opcje postępowania immunosupresyjnego, jednak żadna $z$ nich nie opiera się na mocnych dowodach naukowych. Obecnie istnieje coraz większa zgodność co do przydatności kaplacyzumabu w leczeniu TTP. W opisywanym przypadku nie udało się uzyskać całkowitej remisji (aktywność ADAMTS13 zawsze pozostawała ponizej 40\%). Mimo to pacjentka nie miała dalszych objawów TTP, co dowodzi znaczenia stosowania tego leku i ścisłej obserwacji pacjenta.

Istnieją różne sytuacje predysponujące do rozwoju nabytego TTP, a także innych postaci mikroangiopatii zakrzepowych (TMA, thrombotic microangiopathy). Brak odpowiedzi na leczenie powinien skłaniać do poszukiwania u pacjenta zmian patofizjologicznych stanowiących podstawę procesu chorobowego.

Kolejne doniesienie (Godamunne i wsp.) pochodziło ze Sri Lanki (National Blood Centre, Narahenpita, Sri Lanka). Był to opis przypadku 76-letniego pacjenta, u którego rozpoznano TTP w następstwie ukąszenia przez jadowitego węża [13]. W chwili przyjęcia do szpitala liczba płytek pacjenta wynosiła $111 \times 10^{9} / 1$, stężenie hemoglobiny $-12,8 \mathrm{~g} / \mathrm{dl}$, stężenie mocznika $-76 \mathrm{mg} / \mathrm{dl}$, a kreatyniny $-4,72 \mathrm{mg} / \mathrm{dl}$.

Dwa dni po ukąszeniu węża rozpoczęto stosowanie co drugi dzień zabiegów hemodializy. Liczba płytek stopniowo obniżała się (do $49 \times 10^{9} / 1$ w 4. dniu); wartości czasu protrombinowego i INR pozostawały w granicach normy. Stwierdzono umiarkowaną niedokrwistość ( $\mathrm{Hb}-8,9 \mathrm{~g} / \mathrm{dl})$. We krwi obwodowej występowały schistocyty, co sugerowało rozpoznanie mikroangiopatycznej niedokrwistości hemolitycznej (MAHA, microangiopathic hemolytic anemia). Stężenie dehydrogenazy mleczanowej (ang. lactatate dehydrogenase, LDH) było podwyższone. Poziom ADAMTS13 pacjenta nie został oznaczony ze względów logistycznych.

Dowody kliniczne i laboratoryjne sugerowały rozpoznanie TTP. W 5. dniu po ukąszeniu węża rozpoczęto stosowanie TPE. Zabiegi kontynuowano co 
drugi dzień. Wymieniano 1-1,5 całkowitej objętości osocza, stosując FFP jako płyn zastępczy.

Po 5 zabiegach TPE stan pacjenta uległ poprawie. Liczba płytek krwi wzrosła stopniowo do 150 $\times 10^{9} / 1$. Objawy MAHA ustąpiły, stężenia LDH, mocznika i kreatyniny w surowicy uległy normalizacji. Zabiegi zakończono, a po dalszych 16 dniach pacjent został wypisany do domu.

Autorzy konstatują, że pomimo braku wszystkich objawów towarzyszących zazwyczaj TTP (u pacjenta nie stwierdzano gorączki) rozpoznanie to w opisywanym przypadku wydaje się najbardziej prawdopodobne. Stwierdzają ponadto, że rozpoznanie TTP należy brać pod uwagę u pacjentów, u których wystąpiła trombocytopenia i MAHA także przy prawidłowych wynikach badań krzepnięcia krwi, a szybkie rozpoczęcie TPE może w takiej sytuacji przynieść poprawę.

Ostatnie $\mathrm{z}$ doniesień $\mathrm{w}$ tej grupie (Crosio) pochodziło z Argentyny (Blood Bank, Los Alerces Hospital, Rosario) [14]. Zawierało opis przypadku 27-letniej pacjentki, otrzymującej przetoczenia krwi z powodu znacznej niedokrwistości ( $\mathrm{Hb} 3,9 \mathrm{~g} / \mathrm{dl}$, Ht 11,4\%), z żółtaczką, bez objawów krwawienia. Stwierdzono również małopłytkowość (liczba płytek $95000 / \mathrm{mm}^{3}$ ). Podczas drugiej transfuzji $\mathrm{KKC} z$ wystąpiła nagła duszność z objawami niewydolności oddechowej. W badaniu RTG klatki piersiowej stwierdzono obustronne, heterogenne nacieki, w badaniach laboratoryjnych po transfuzji - stężenie $\mathrm{Hb} 10,5 \mathrm{~g} / \mathrm{dl}, \mathrm{Ht}-31,2 \%$, liczba płytek $45400 / \mathrm{mm}^{3}$, ponadto występowała hipoksemia. We krwi obwodowej stwierdzono obecność pojedynczych schistocytów.

Zastosowano leczenie podtrzymujące i wentylację nieinwazyjną, uzyskując poprawę stanu układu oddechowego. We krwi dawcy wykryto obecność przeciwciał antyleukocytarnych, co mogło przemawiać za rozpoznaniem niepożądanej reakcji poprzetoczeniowej (TRALI, transfusion related acute lung injury).

Jednak ze względu na stwierdzenie u pacjentki niedokrwistości i małopłytkowości, a także podwyższonego stężenia LDH oraz objawów hemolizy, podejrzewano także TTP. Rozpoczęto stosowanie plazmaferezy. Powikłaniem jednego z zabiegów był wstrząs hipowolemiczny, będący następstwem uszkodzenia żyły centralnej w trakcie wprowadzenia do niej cewnika naczyniowego. Seria zabiegów przyniosła jednak ostatecznie poprawę stanu pacjentki.

Autor doniesienia stwierdza, że wprawdzie u pacjentki nie wykonano badania ADAMTS13, jednak objawy kliniczne, a także wyniki badań laboratoryjnych i dobra odpowiedź na zabiegi TPE przemawiają za rozpoznaniem TTP. Ponadto podkreśla, że ze względu na znaczną śmiertelność obserwowaną $\mathrm{w}$ takich przypadkach konieczne jest zachowanie czujności w celu szybkiego ustalenia rozpoznania i zastosowania w porę właściwego leczenia.

\section{Kardiologia}

Praca pochodząca $z$ Rosji (Kulikova i wsp.) została przedstawiona $\mathrm{w}$ ramach sesji poświęconej prezentacji wyników badań klinicznych [15]. Dotyczyła zastosowania TPE u pacjentów $z$ kardiomiopatią rozstrzeniową i zaburzeniami rytmu związanymi z zapaleniem mięśnia sercowego.

Autoprzeciwciała przeciw mięśniowi sercowemu (AAB, cardiac auto-antibodies) są często wykrywane u pacjentów $\mathrm{z}$ zapalną kardiomiopatią rozstrzeniową (iDCM, inflammatory dilated cardiomyopathy) i arytmią wywołaną zapaleniem mięśnia sercowego.

Eliminacja $\mathrm{AAB}$ za pomocą aferezy, jak również stosowanie leków immunosupresyjnych wpływają na poprawę czynności lewej komory, brakuje jednak danych dotyczących łącznego wykorzystania leków immunosupresyjnych i aferezy. Celem badania była ocena klinicznej skuteczności stosowania TPE u pacjentów $z$ zapaleniem mięśnia sercowego $\mathrm{w}$ porównaniu $\mathrm{z}$ pacjentami leczonymi bez TPE.

W grupie TPE znalazło się łącznie 19 pacjentów z iDCM i 22 pacjentów z arytmią. Wszyscy pacjenci $z$ grupy TPE zostali poddani wymianie pojedynczej objętości osocza $z$ zastosowaniem 0,9-procentowego roztworu $\mathrm{NaCl}$ jako płynu zastępczego. Kolejnych 19 pacjentów z iDCM i 26 pacjentów $z$ arytmią stanowiło grupę kontrolną. Niektórzy z pacjentów przyjmowali leki immunosupresyjne. U wszystkich pacjentów występował wysoki poziom co najmniej dwóch AAB.

U pacjentów $z$ grupy TPE obserwowano znaczące obniżenie poziomu AAB bezpośrednio po zabiegu, a także w czasie dalszej obserwacji. Obserwowano także znaczącą poprawę stanu klinicznego w grupach pacjentów, u których zastosowano TPE.

Autorzy stwierdzają, że zabiegi TPE wpływają na poprawę czynności serca, a także codziennej aktywności pacjentów $z$ iDCM i arytmiami spowodowanymi zapaleniem mięśnia sercowego. Jest to metoda bezpieczna, o dużej skuteczności i w niektórych przypadkach umożliwia ograniczenie dawek leków immunosupresyjnych. 


\section{Płyn zastępczy stosowany w zabiegach TPE}

Pierwsza $z$ prac omawiających to zagadnienie (Kim i wsp.) pochodziła $z$ Korei (Department of Laboratory Medicine, University of Ulsan, College of Medicine and Asan Medical Center, Seul) [16]. Autorzy opisali wyniki analizy retrospektywnej dotyczącej danych na temat zabiegów TPE wykonywanych u pacjentów $z$ przypadkami mikroangiopatii zakrzepowych (TMA, thrombotic microangiopathy) przy użyciu jako płynu zastępczego FFP albo osocza o obniżonej zawartości krioprecypitatu (CRP, cryoprecipitate-reduced plasma). Celem badania było porównanie efektów stosowania CRP i FFP $\mathrm{w}$ przebiegu pojedynczego zabiegu TPE. U pacjentów badano i porównywano liczbę krwinek płytkowych i poziom dehydrogenazy mleczanowej przed zabiegami i po ich wykonaniu.

Badaniem objęto 12 pacjentów w wieku 17-76 lat, $z$ różnymi postaciami TMA. U pacjentów tych wykonano łącznie 150 zabiegów (73 przy użyciu FFP i 77 przy użyciu CRP). Mediana całkowitej liczby sesji TPE/pacjenta wynosiła 11 (8-21).

Nie wykazano istotnej różnicy statystycznej procentowej zmiany liczby płytek krwi i stężenia LDH po zabiegach pomiędzy pacjentami otrzymującymi FFP i CRP. Jednak absolutny przyrost liczby płytek okazał się większy u pacjentów otrzymujących CRP. Autorzy wnioskują, że zastosowanie CRP może być przydatne w przypadku zabiegów TPE u pacjentów z TMA opornych na leczenie.

Drugie $z$ doniesień (Kohli i wsp.) pochodziło z Wielkiej Brytanii i przedstawiało wyniki wieloośrodkowego obserwacyjnego badania kohortowego [17]. Celem tego badania było porównanie zmian parametrów hemostatycznych w następstwie zabiegów TPE przy zastosowaniu dwóch różnych płynów zastępczych (5-procentowy roztwór albuminy w porównaniu $z$ mieszaniną roztworu albuminy i Gelofusine $\left.{ }^{\circledR 2}, 50: 50\right)$ u pacjentów $z$ niskim ryzykiem krwawienia.

W próbkach krwi żylnej pacjentów pobieranych przed i po każdym zabiegu oznaczano czynniki krzepnięcia (II, V, VII, VII, VIII, IX, X, XI, XII, XIII i fibrynogen).

$\mathrm{U} 7$ pacjentów $\mathrm{z}$ pierwszej grupy ( $\mathrm{w}$ wieku 23-69 lat) wykonano średnio po 4 zabiegi z zastosowaniem 5-procentowego roztworu albuminy jako płynu zastępczego. Najczęstszym wskazaniem do zabiegów było przygotowanie pacjenta do przeszczepienia nerki niezgodnej w układzie ABO. W kohorcie drugiej, 8 pacjentów (w wieku 27-70

${ }^{2}$ Gelofusine - roztwór do infuzji zawierający 4\% płynnej modyfikowanej żelatyny i chlorek sodu. lat) również przebyło średnio po 4 zabiegi, ale otrzymując mieszaninę roztworu albuminy i Gelofusine ${ }^{\circledR}$ ). Wskazania do zabiegów były w tej grupie różne, ale w większości nie dotyczyły chorób nerek.

Poziomy wszystkich parametrów hemostatycznych badanych w obu kohortach uległy po zabiegach obniżeniu w stosunku do wartości wyjściowej, przy czym u pacjentów otrzymujących roztwór albuminy największy procentowy spadek dotyczył czynnika XII, a u pacjentów otrzymujących mieszankę czynnika XIII. Spadek procentowy obserwowany pomiędzy pierwszym a ostatnim zabiegiem był w obu grupach najniższy dla czynnika IX.

Natomiast porównując zmiany średnich wartości poszczególnych czynników krzepnięcia przed pierwszym i po ostatnim zabiegu TPE, nie stwierdzono istotnych różnic pomiędzy obiema grupami. Te wstępne wyniki wskazują, że zmiany parametrów hemostazy są podobne w przypadku obu zastosowanych w tym badaniu płynów zastępczych.

\section{Podsumowanie}

Plazmafereza lecznicza - przede wszystkim lecznicza wymiana osocza - pozostaje szeroko stosowaną techniką hemaferezy leczniczej, znajdującą zastosowanie w leczeniu wielu chorób. Wśród prezentowanych $\mathrm{w}$ ramach omawianego kongresu prac całkowicie zabrakło tym razem doniesień poświęconych bardziej nowoczesnym, selektywnym metodom oczyszczenia osocza.

Analizując treść doniesień prezentowanych w czasie naukowych kongresów, trzeba jednak wziąć pod uwagę fakt, że nie zawsze odzwierciedlają one aktualne trendy i skalę zastosowania hemaferezy leczniczej.

Najwięcej prezentowanych w ramach omawianego kongresu doniesień (8) pochodziło z Hiszpanii, co jednak przypuszczalnie można przynajmniej częściowo wiązać $z$ faktem, że tam właśnie (w Barcelonie) miały się pierwotnie odbywać obrady. Zmiana charakteru kongresu na wirtualny nastąpiła już po zgłoszeniu prac, w związku $z$ wybuchem pandemii COVID-19.

Większość omawianych doniesień poświęcono zastosowaniom plazmaferezy w przypadkach chorób układu nerwowego i TTP. Oczywiście wynika to w znacznej mierze ze specyfiki działania poszczególnych ośrodków stosujących plazmaferezę, a niekiedy zapewne także indywidualnych zainteresowań poszczególnych autorów.

Szczególnie ciekawe wydaje się doniesienie dotyczące badania klinicznego mającego na celu ocenę możliwości zastosowania TPE w przypadkach choroby Alzheimera (badanie AMBAR) [5]. 
Wprawdzie doniesienie przedstawione w ramach kongresu zawiera jedynie wstępną ocenę wykonalności i bezpieczeństwa stosowania TPE przy wykorzystaniu roztworu albumin jako płynu zastępczego u pacjentów z $\mathrm{AD}$, jednak w 2020 roku opublikowano już także wyniki fazy $2 \mathrm{~b} / 3$ badania AMBAR, sugerujące, że stosowanie TPE u chorych $z$ AD może spowalniać pogorszenie ich stanu zdrowia i utratę zdolności poznawczych. Za celowe uważa się zatem przeprowadzenie dalszych badań [18].

Jak się wydaje, w wielu stanach klinicznych plazmafereza lecznicza może obecnie tracić na znaczeniu $\mathrm{w}$ związku $\mathrm{z}$ wprowadzaniem alternatywnych metod leczenia, nadal jednak pozostaje przydatna jako metoda uzupełniająca i pomocnicza.

\section{Piśmiennictwo}

1. Naznin B, Afroz T. Outcomes of therapeutic plasma exchange; Single Tertiary Center Experience in Bangladesh. Vox Sanguinis 2020; 115 (suppl. s1): 313.

2. Wijesiri RD. A descriptive study of indications, complications and response of patients who undergo therapeutic plasma exchange at National Hospital, Sri Lanka. Vox Sanguinis 2020; 115 (suppl. s1): 313 .

3. Padmanabhan A, Connelly-Smith L, Aqui N, et al. Guidelines on the use of therapeutic apheresis in clinical practice - evidence-based approach from the Writing Committee of the American Society for Apheresis: the eighth special issue. J Clin Apher. 2019; 34(3): 171-354, doi: 10.1002/jca.21705, indexed in Pubmed: 31180581.

4. Rosiek A, Lachert E, Antoniewicz-Papis J, et al. Two decades of therapeutic apheresis at the Warsaw Institute of Hematology and Transfusion Medicine. Vox Sanguinis 2020; 115 (suppl. s1): 310.

5. Lozano M, Boada M, Lopez O, et al. Transfusion medicine in Alzheimer's disease: apheresis procedures as a therapeutic approach (AMBAR Study). Vox Sanguinis 2020; 115 (suppl. s1): 309.

6. Rivas I, Ortiz A, Amarilla I, et al. Effectiveness of therapeutic plasma exchange in neurological patients. Experience in a third level hospital. Vox Sanguinis 2020; 115 (suppl. s1): 311.

7. Kaur R, Mittal K, KaurR, et al. Role of therapeutic plasma exchange (TPE) in neurological diseases: our experience from a
Tertiary Care Centre in Northern India. Vox Sanguinis 2020; 115 (suppl. s1): 312.

8. Ramos-Coronado A, Diaz E, Cienfuegos E. Seven-year records of Guillain Barre syndrome patients treated with albumin plasma exchange in a University Hospital, a follow up descriptive study. Vox Sanguinis 2020; 115 (suppl. s1): 312.

9. Al Riyami R, Al Shaikhli K, Al Zaabi M. Therapeutic plasma exchange for neurology patients - an experience from a National Neuroscience Centre. Vox Sanguinis 2020; 115 (suppl. s1): 312 .

10. Guyatt G, Gutterman D, Baumann MH, et al. Grading strength of recommendations and quality of evidence in clinical guidelines: report from an american college of chest physicians task force. Chest. 2006; 129 (1): 174-181, doi: 10.1378/chest.129.1.174, indexed in Pubmed: 16424429.

11. Guyatt GH, Oxman AD, Vist GE, et al. GRADE Working Group. GRADE: an emerging consensus on rating quality of evidence and strength of recommendations. BMJ. 2008; 336(7650): 924926, doi: 10.1136/bmj.39489.470347.AD, indexed in Pubmed: 18436948.

12. Campos E, Garzo A, Hernandez L, et al. Acquired refractory thrombotic thrombocytopenic purpura: a case report. Vox Sanguinis 2020; 115 (suppl. s1): 314.

13. Godamunne A, Kumari T. A case report of thrombotic thrombocytopenic purpura following a snake bite. Vox Sanguinis 2020; 115 (Suppl. s1): 327-328.

14. Crosio E. Transfusion-associated acute lung injury in a patient with thrombotic thrombocytopenic purpura. Vox Sanguinis 2020; 115 (Suppl. s1): 338.

15. Kulikova V, Nedostup A, Blagova O, et al. Plasma exchange in patients with inflammatory dilated cardiomyopathy and arrhythmias due to myocarditis. Vox Sanguinis 2020; 115 (Suppl. s1): 18.

16. Kim H, Yang J, Ko D, et al. Is cryoprecipitate reduced plasma efficacious replacement fluid for therapeutic plasma exchange in thrombotic microangiopathy?: A single center retrospective experience. Vox Sanguinis 2020: 115 (suppl. s1): 308-309.

17. Kohli R, Platton S, Manson L, et al. Effect of different replacement fluids on haemostatic parameters during therapeutic plasma exchange. Vox Sanguinis 2020; 115 (Suppl. s1): 310.

18. Boada M, López OL, Olazarán J, et al. A randomized, controlled clinical trial of plasma exchange with albumin replacement for Alzheimer's disease: Primary results of the AMBAR Study. Alzheimers Dement. 2020; 16(10): 1412-1425, doi: 10.1002/ alz.12137, indexed in Pubmed: 32715623. 